\title{
IMPLEMENTASI MANAJEMEN SARANA PRASARANA PENDIDIKAN DI MADRASAH ALIYAH SWASTA
}

\author{
Nur Rahmi Sonia \\ IAIN Ponorogo \\ nurrahmisonia@gmail.com
}

DOI: $10.35719 /$ jieman.v3i2.95

\begin{abstract}
Abstrak
Artikel ini menjelaskan mengenai hasil implementasi manajemen sarana prasarana pada sebuah Madrasah Aliyah (MA) swasta di Beton, Ponorogo, Jawa Timur. Jenis penelitian yang digunakan dalam penelitian ini adalah penelitian kualitatif dengan pendekatan studi kasus. Teknik pengumpulan data dalam penelitian ini dilakukan dengan cara triangulasi yang dilakukan dengan menggunakan observasi, wawancara dan dokumentasi dari sumber yang sama, sedangkan teknik analisis data yang digunakan adalah pengumpulan data, reduksi data, display data, dan penarikan kesimpulan. Hasil penelitian ini adalah bahwa implementasi manajemen sarana prasarana di MA ini terdiri dari proses perencanaan, pengadaan, pemeliharaan dan pengawasan. Pertama, perencanaan terdiri dari kegiatan penyusunan daftar kebutuhan, estimasi biaya, menetapkan skala prioritas dan menyusun rencana pengadaan. Kedua, pengadaan terdiri dari pembelian, penerimaan hibah, penyewaan, pinjaman dan rekondisi. Ketiga, pemeliharaan dilakukan dengan cara membentuk tim pemeliharaan, menyusun daftar pemeliharaan, menentukan jadwal pemeliharaan secara rutin dan berkala, dan evaluasi pemeliharaan. Keempat, pengawasan dilakukan melalui Wakil Kepala Sekolah Bidang Sarana dan Prasarana melaporkan hasil pengawasan kepada kepala


JIEMAN: Journal of Islamic Educational Management

sekolah, penyusunan laporan pengawasan, dan pelaporan kepada pihak yayasan setiap enam bulan sekali dan setahun sekali.

Kata Kunci: manajemen sarana prasarana pendidikan, Madrasah Aliyah

\begin{abstract}
This article is to explain the results of the implementation of infrastructure management at a private Madrasah Aliyah, Beton, Ponorogo, East Java. The type of research used in this research is qualitative research with a case study approach. The data collection technique in this study was carried out by triangulation which was carried out using observations, interviews and documentation from the same source. While the data analysis techniques used are data collection, data reduction, data display, and drawing conclusions. The results of this study are that the implementation of infrastructure management at this madrasah consists of the planning, procurement, maintenance and supervision processes. First, planning consists of preparing a list of needs, estimating costs, setting priorities and compiling a procurement plan. Second, procurement consists of purchasing, receiving grants, leasing, lending and reconditioning. Third, maintenance is carried out by forming a maintenance team, compiling a maintenance list, determining routine and periodic maintenance schedules, and evaluating maintenance. Fourth, supervision is carried out through the vice principal for infrastructure reporting the results of supervision to the principal, preparing supervision reports, and reporting to the foundation once a month and once a year.
\end{abstract}

Keywords: infrastructure management of education, Islamic Senior High School

\title{
Pendahuluan
}

Pendidikan merupakan sarana peningkatan sumber daya manusia dalam suatu negara. ${ }^{1}$ Bangsa yang maju adalah bangsa yang

1 Nanang Fattah, Ekonomi Dan Pembiayaan Pendidikan (Bandung: Rosdakarya, 2012).

238 Vol. 1 No. 1, November 2019 
peduli terhadap pendidikan, yang dibuktikan dengan kualitas sumber daya manusia bangsanya. ${ }^{2}$ Selain itu, pendidikan juga dapat memberikan kesempatan bagi setiap peserta didik untuk dapat mengembangkan potensi-potensi yang dimilikinya. Salah satu tempat dalam mengembangkan potensi adalah sekolah. ${ }^{3}$ Sekolah harus dapat memberikan pelayanan publik, khususnya pelayanan untuk peserta didik yang menuntut pendidikan yang nantinya dapat berpengaruh pada lingkungan ataupun iklim yang baik sehingga mendorong siswa untuk termotivasi secara intrinsik. ${ }^{4}$

Keberhasilan program sekolah sebagai lembaga pendidikan formal melalui proses belajar mengajar yang sangat dipengaruhi oleh berbagai faktor mulai dari kurikulum, sarana dan prasarana, sumber daya yang dalam hal ini tenaga pendidik, serta pengelolaannya. nya agar proses pembelajaran berjalan dengan tertib dan lancar. ${ }^{5}$ Selain itu. Subroto menyatakan bahwa terdapat tujuh komponen sekolah yang harus diperhatikan dalam mendukung pembelajaran yaitu kurikulum dan program pengajaran, tenaga kesiswaan, keuangan, sarana dan prasarana pendidikan, pengelolaan hubungan sekolah dan masyarakat, serta pelayanan khusus lembaga pendidikan. ${ }^{6}$

Sebagai lembaga pendidikan, sekolah memerlukan dukungan sarana dan prasarana pendidikan. Sarana dan prasarana merupakan

${ }^{2}$ Nur Rahmi Sonia, Manajemen Pendidikan: Tinjauan, Teori Dan Praktis (Bandung: Widina, n.d.), 119.

${ }^{3}$ Cut Zahri Harun Trisnawati and Nasir Usman, "Manajemen Sarana Dan Prasarana Pendidikan Dalam Meningkatkan Mutu Pembelajaran Di SD Negeri Lamteubee Aceh Besar,” Jurnal Magister Administrasi Pendidikan 7, no. 1 (n.d.).

${ }^{4}$ Mohammad Nurul Huda, "Optimalisasi Sarana Dan Prasarana Dalam Meningkatkan Prestasi Belajar Siswa,” Ta'dibi: Jurnal Manajemen Pendidikan Islam 6, no. 2 (n.d.): 51.

${ }^{5}$ Alex Aldha Yudhi, "Pengembangan Mutu Pendidikan Ditinjau Dari Segi Sarana Dan Prasarana (Sarana Dan Prasarana PPLP),” Cerdas Syifa 1, no. 1 (2012): 19.

6 Huda, "Optimalisasi Sarana Dan Prasarana Dalam Meningkatkan Prestasi Belajar Siswa,” 53. 
material pendidikan yang sangat penting. ${ }^{7}$ Banyak sekolah yang memiliki sarana dan prasarana lengkap sehingga dapat menunjang proses pendidikan di sekolah. ${ }^{8}$ Namun sayangnya, kondisi tersebut tidak berlangsung lama. Tingkat kualitas dan kuantitas sarana dan prasarana tidak dapat dipertahankan secara terus menerus. Sementara itu, bantuan sarana dan prasarana tidak datang setiap saat. Oleh karena itu, dibutuhkan upaya pengelolaan sarana dan prasarana secara baik agar kualitas dan kuantitas sarana dan prasarana dapat dipertahankan dalam waktu yang relatif lebih lama. ${ }^{9}$

Hal tersebut dialami MA Ar-Rosyidiyah bahwa jika didasarkan pada standar sarana dan prasarana luas lahan sekolah harus dapat digunakan secara efektif untuk membangun prasarana sekolah berupa bangunan gedung dan tempat bermain/olahraga tetapi luas lahan MA Ar-Rosyidiyah tidak sesuai dengan sesuai ketentuan standar sarana dan prasarana. Kemudian, dalam hal perencanaan pengadaan sarana dan prasarana, pihak madrasah mengajukan proposal untuk menerima bantuan dari pihak yayasan tetapi tidak semua proposal yang diajukan dari pihak madrasah mendapatkan hasil yang diinginkan sehingga proses pembelajaran kurang optimal karena sarana dan prasarana kurang memadai. Selain itu dalam proses pengelolaan sarana dan prasarana masih belum berjalan dengan optimal dimulai dari penginventarisan, pemakaian pemeliharaan, sampai penghapusan sarana dan prasarana. Oleh karena itu, proses pengelolaan sarana dan prasarana ini masih dibutuhkannya perbaikan. ${ }^{1}$

${ }^{7}$ Suharsimi Arikunto and Lia Yuliana, Manajemen Pendidikan (Yogyakarta: Aditya Media, 2009), 273.

${ }^{8}$ Suryani, "Manajemen Sarana Prasarana Dan Prestasi Belajar Peserta Didik," Al-Idarah:Jurnal Kependidikan Islam 7, no. 2 (n.d.).

${ }^{9}$ Barnawi and Muhammad Arifin, Manajemen Sarana E Prasarana Sekolah (Yogyakarta: Ar-Ruzz Media, 2017), 47.

1 Ike Malaya Sinta, "Manajemen Sarana Dan Prasarana," Jurnal Islamic: Education Manajemen 4, no. 1 (n.d.).

240 Vol. 1 No. 1, November 2019 
Hal senada juga dialami oleh SD Negeri 28o Desa Aek Manggis Kecamatan Batang Natal, Kabupaten Mengdailing Natal, dari aspek perencanaan dilakukan dengan baik, pihak kepala sekolah melibatkan semua guru namun kendalanya adalah dana yang masih kurang dan hanya diperoleh dari dana BOS. ${ }^{1}$ Dengan demikian, proses perencanaan harus direncanakan dengan baik dengan mengalisis kebutuhan dan dana. Hal yang sama juga terjadi di SD IT Kautsar Ilmi di mana sarana dan prasarana yang ada sudah cukup baik, namun permasalahannya adalah pemeliharaan serta pengadaan sarana dan prasarana belum optimal, terutama dalam pemeliharaan sarana dan prasarana pendidikan yang ada di sekolah ini masih belum terlaksana sesuai standar, seperti yang seharusnya dilakukan serta pemanfaatan belum sepenuhnya bisa dimanfaatkan oleh semua pihak yang memakai sarana dan prasarana pendidikan tersebut. $^{1}$ Dengan melihat permasalahan têrsebut diperlukan manajemen pemeliharaan dan pengadaan sarana dan prasarana dengan komprehensif dan kontinyu agar pemanfaatan sarana dan prasarana tersebut dapat dilaksanakan dengan optimal.

Permasalahan mengenai sarana prasarana juga terjadi di SD Negeri 1 Puter yang terletak di Desa Puter Kecamatan Kembangbahu Kabupaten Lamongan, dimana kondisi gedung sangat memprihatinkan dan cenderung membahayakan keselamatan belajar siswa. Dengan kondisi dinding yang retak, atap yang berlubang dan lantai yang sebagian hancur, hal tersebut sering membuat baik guru maupun siswa-siswi merasa takut apabila sewaktu-waktu gedung roboh. Apalagi saat musim penghujan yang terkadang disertai angin. Hal ini membuat guru dan para orang tua cukup khawatir akan keselamatan anak-anak mereka. Sehingga ketika turun hujan, pihak

1 Maryam Jambak, "Manajemen Sarana Dan Prasarana SD Negeri Pada Daerah Terpencil (Studi Kasus SDN 280 Aek Manggis Kecamatan Batang Kabupaten Mandiling Natal"," n.d.

1 Muhammad Yamin, Tobari, and Missriani, ${ }^{2 “ M a n a j e m e n ~ S a r a n a ~ D a n ~}$ Prasarana Dalam Meningkatkan Hasil Belajar Siswa Di SD IT Kautsar Ilmi Tanjung Raja,” Jurnal Intelektualita: Keislaman, Sosial, Dan Sains 9, no. 1 (n.d.). 
sekolah terpaksa memulangkan siswanya untuk menghindari hal-hal yang tidak diinginkan. ${ }^{1}$

Tidak berhenti di situ saja, di SD Negeri Lamteubee Aceh Besar ternyata juga mengalami kekurangan dalam sarana dan prasarana yang dibutuhkan baik dari gedungnya, serta fasilitas lainnya masih kurang optimal, dari segi pengadaan masih kurang, pemanfaatan masih kurang terlaksana dan belum sepenuhnya dimanfaatkan, pemeliharaan sarana dan prasarana masih kurang terlaksana oleh semua pihak yang memakai dan kurang diperhatikan oleh pihak-pihak pengelola SD Negeri Lamteubee Aceh Besar. ${ }^{1}$

Dengan demikian, dalam proses pembelajaran memerlukan sarana dan prasarana yang memadai dan sesuai dengan kebutuhan. Apabila sarana dan prasarana tersebut telah diadakan, hendaknya dimanfaatkan dan dikelola dengan baik. Kegiatan pengelolaan sarana prasarana meliputi kegiatan perencanaan, pengadaan, pengawasan, penyimpanan, inventarisasi dan penghapusan serta penataan $^{1}$. Oleh karena itu, dalam mengatasi permasalahan mengenai sarana dan prasarana diperlukan upaya manajemen sarana dan prasarana secara baik agar kualitas dan kuantitas sarana dan prasarana dapat dipertahankan dalam waktu yang relatif lebih lama, sehingga proses pembelajaran dapat dilakukan dengan maksimal serta dapat meningkatkan prestasi belajar siswa.

Dengan adanya manajemen sarana dan prasarana yang optimal diharapkan dapat menciptakan kondisi yang menyenangkan baik bagi guru maupun murid untuk berada di sekolah, sehingga secara langsung dengan adanya sarana dan prasarana yang baik

1 Fathurrahman and Rizky Oktaviani Putri Dew13, "Manajemen Sarana Dan Prasarana Pendidikan Mendukung Proses Belajar Siswa Di SDN Puter 1 Kembangbahu Lamongan," Reforma: Jurnal Pendidikan Dan Pembelajaran 8, no. 1 (n.d.).

1 Trisnawati and Usman, "Manajemen Sarana Đan Prasarana Pendidikan Dalam Meningkatkan Mutu Pembelajaran Di SD Negeri Lamteubee Aceh Besar.”

1 Yamin, Tobari, and Missriani, "Manajemen Saŕana Dan Prasarana Dalam Meningkatkan Hasil Belajar Siswa Di SD IT Kautsar Ilmi Tanjung Raja.”

242 Vol. 1 No. 1, November 2019 
sangat membantu keberhasilan dalam meningkatkan prestasi belajar siswa. Semakin lengkap yang dimanfaatkan secara optimal, sarana dan prasarana suatu sekolah tentu semakin mempermudah murid dan guru untuk mencapai target secara bersama- sama. ${ }^{1}$

Lokus penelitian ini adalah sebuah Madrasah Aliyah (MA) swasta yang terletak di Jalan Noyorono Nomor 25 Dusun Mranggen Desa Beton Kecamatan Siman Kabupaten Ponorogo Provinsi Jawa Timur, yang bisa dikatakan madrasah pinggiran dengan jumlah siswa terbilang sedikit namun memiliki prestasi siswa yang cukup cemerlang tiap tahunnya baik tingkat kabupaten maupun provinsi. Mengingat prestasi MA ini cukup cemerlang, dalam mendukung dan meningkatkan prestasi belajar siswa guna meningkatkan prestasi madrasah, sarana prasarana membawa peran penting di dalamnya. Oleh karena itu, dalam rangka peningkatan pelayanan pendidikan di madrasah, MA ini berusaha memenuhi sarana dan prasarana pendidikan agar proses belajar mengajar di madrasah dapat berjalan dengan lancar sehingga visi, misi, dan tujuan madrasah tercapai. Di antara sekian banyak sekolah-sekolah yang ada di wilayah Beton, MA ini adalah madrasah swasta Islam yang mampu mengelola sarana prasarana yang ada dengan cukup optimal sehingga prestasi siswa selalu meningkat.

Berdasarkan pra penelitian mengenai manajemen sarana dan prasarana di MA ini memperlihatkan bahwa sarana dan prasaran pada lembaga pendidikan tersebut cukup dikelola dengan baik, sehingga sarana prasarana tersebut dapat digunakan dengan maksimal. Pernyataan di atas tersebut didukung informasi yang dinyatakan oleh Kepala Madrasah bahwa gedung-gedung sebagai prasarana penujang belajar siswa sudah tersedia. Peralatan pendukung pembelajaran juga tersedia dengan kondisi yang baik. Bahkan madrasah berusaha memfasilitasi segala kebutuhan siswa untuk membawa nama baik madrasah ke kompetisi dalam meningkatkan prestasi madrasah.

1 Huda, "Optimalisasi Sarana Dan Prasaraf́a Dalam Meningkatkan Prestasi Belajar Siswa.” 
Sarana dan prasarana yang baik akan sangat membantu keberhasilan dalam meningkatkan mutu pendidikan. Semakin lengkap sarana dan prasarana serta dapat dimaanfaatkan secara optimal maka mutu dan kualitas siswa dan tujuan pembelajaran dapat terwujud. Oleh karena itu, diperlukan manajemen sarana prasarana yang baik dan optimal.

\section{Pembahasan}

\section{Perencanaan Sarana Prasarana di Madrasah Aliyah Swasta}

Sarana pendidikan adalah segala sesuatu yang meliputi peralatan dan perlengkapan yang langsung digunakan dalam proses pendidikan di sekolah, seperti gedung, ruangan, meja, kursi, alat peraga, dan buku pelajaran. Adapun prasarana adalah semua komponen yang secara tidak langsung menunjang jalannya proses belajar mengajar di sebuah lembaga pendidikan, seperti jalan menuju skeolah, halaman sekolah, dan tata tertib sekolah. ${ }^{1}$ Pengelolaan sarana prasarana pendidikan adalah kegiatan menata, mulai dari merencanakan kebutuhan, pengadaan, inventarisasi, penyimpanan, pemeliharaan, penggunaan, penghapusan dan pengawasan secara tepat guna dan tepat sasaran ${ }^{1}$. Proses manajemen sarana prasarana pendidikan diawali dengan perencanaan. ${ }^{1}$

Perencanaan sarana dan prasarana sekolah dapat didefinisikan sebagai keseluruhan proses perkiraan secara matang rancangan pembelian, pengadaan, rehabilitasi, distribusi atau pembuatan peralatan, dan perlengkapan yang sesuai dengan kebutuhan oleh sekolah. ${ }^{2}$ Hal tersebut senada dengan Ananda dan Banurea bahwa Perencanaan sarana dan prasarana berarti merinci

1 Soetopo, Administrasi Pendidikan (Malang: IKIP Malang, 1998), 134-35.

1 Imam dan Ara Hidayat Machali, "The Handbook of Education Management: Teori Dan Praktik," n.d., 198.

1 Barnawi and Arifin, Manajemen Sarana E Prasarana Sekolah, 48.

2 Oki Dermawan, Manajemen Fasilitas Pendidikan (Jakarta: Edu Pustaka, n.d.), 29 . 
rancangan pembelian, pengadaan, rehabilitasi, distribusi atau pembuatan perlalatan dan perlengkapan sesuai dengan kebutuhan oleh sekolahan yang melalui proses rancangan secara matang ${ }^{2}$. Dengan demikian perencanaan sarana dan prasarana haruslah merujuk kepada keseluruhan proses penyusunan daftar kebutuhan, pembelian atau pengadaan, inventarisasi, penyimpanan, pemeliharaan.

Pada proses perencanaan sarana prasarana pada MA ini berada di bawah tanggung jawab kepala madrasah dan didelegasikan kepada wakil kepala madrasah bidang sarana prasarana. Perencanaan terhadap sarana prasarana ini dilaksanakan oleh pihak madrasah agar dapat dikelola dengan baik dan tujuan yang diharapkan dapat tercapai dengan baik pula. Dalam perencanaan sarana prasarana MA ini terdapat pihak-pihak yang terlibat di dalamnya yaitu Kepala Madrasah, Wakil Kepala Madrasah, Guru, Bendahara, dan Karyawan Tata Usaha. Hal ini telah sesuai dengan unsur yang terlibat dalam perencanaan sarana prasarana yang dikemukakan oleh Nur Aedi bahwa unsur-unsur yang perlu dilibatkan dalam perencanaan sarana prasarana yaitu kepala sekolah, wakil kepala sekolah, guru, kepala tata usaha dan bendahara, serta komite sekolah. ${ }^{2}$

Kemudian berkaitan dengan sumber anggaran dana untuk lembaga pendidikan berasal dari berbagai pihak. Sama halnya sumber anggaran dana yang diterima oleh MA ini berasal dari pemerintah dan swasta serta swadaya dari wali murid. Hal ini sesuai dengan sumber anggaran dana dalam perencanaan yang dikemukakan oleh Direktorat Tenaga Kependidikan bahwa sumber anggaran dana pengadaan, pemeliharaan, penghapusan, dan lain-

2 Rusydi Ananda and Oda Kinanta Banurea, "'Manajemen Sarana Dan Prasarana Pendidikan," n.d.

2 Nur Aedi, Manajemen Sarana Dan Prasaraná (Jakarta: Insan Rabbani, n.d.).

Vol. 3 No. 2, Desember 2021 
lain dibebankan dari APBN/APBD, dan bantuan dari $\mathrm{BP}_{3}$ atau Komite Sekolah. ${ }^{2}$

Perencanaan sarana prasarana di ini dilaksanakan sebelum awal tahun pembelajaran melalui beberapa langkah-langlah perencanaan. Langkah pertama adalah membuat jadwal rapat terlebih dahulu bersama dengan kepala madrasah, dalam langkah ini menentukan jadwal koordinasi terlebih dahulu, agar dalam proses koordinasi tersebut tidak mengganggu proses belajar mengajar di madrasah. Langkah kedua adalah rapat koordinasi. Dalam langkah ini seluruh pihak yang terlibat mengikuti rapat perencanaan sarana prasarana yang sebelumnya telah ditentukan jadwalnya oleh kepala madrasah dan wakil kepala madrasah. Langkah ketiga adalah menampung segala sesuatu usulan dari guru-guru terkait sarana prasarana apa saja yang dibutuhkan dalam pembelajaran satu tahun kedepan. Langkah keempat adalah melakukan penyusunan kebutuhan dan rencana pengadaannya, setelah proses penampungan usulan sarana prasarana dilakukan penyusunan kebutuhan berdasarkan skala prioritas sarana prasarana yang sedang dibutuhkan.

Langkah kelima adalah pengecekan daftar rencana dengan arana prasarana yang ada di madrasah, yakni memadukan antara skala prioritas yang ada dengan realita yang ada di madrasah. Hal ini dilakukan untuk meminimalisir pengadaan sarana prasarana ganda dan memaksimalkan sarana prasarana yang ada. Langkah keenam adalah memadukan daftar sarana prasarana tersebut dengan dana yang ada. Setelah proses memadukan dengan realita atau kondisi sarana prasarana di madrasah perlu dilakukan pemaduan dengan dana yang ada, sehingga dapat diketahui apakah sarana prasarana yang nantinya akan diadakan cukup anggaran dalam satu tahun ajaran ke depan. Langkah terakhir madrasah penetapan rencana,

2 Direktorat Tenaga Kependidikan, Manajemen Sarana Prasarana Pendidikan Persekolahan Berbasis Sekolah (Departemen Pendidikan Nasional, n.d.).

246 Vol. 1 No. 1, November 2019 
setelah semua langkah di atas dilakukan maka selanjutnya penetapan rencana yang disusun dalam sebuah dokumen.

Langkah tersebut di atas telah sesuai dengan pendapat yang dikemukakan oleh Haris bahwa langkah-langkah praktis dalam perencanaan sarana dan prasarana adalah menampung semua usulan dari pendidik dan tenaga kependidikan tentang kebutuhan sarana dan prasarana, menyusun kebutuhan dan rencana pengadaan sarana dan prasarana dalam kurun waktu tertentu misalnya satu semester, satu tahun, atau lima tahun. Kemudian memadukan rencana kebutuhan dengan sarana dan prasarana yang sudah ada. Selanjutnya memadukan rencana/kebutuhan sarana dan prasarana dengan kemampuan financial untuk pengadaannya. Selain itu membuat skala prioritas pengadaan sarana dan prasarana. Dan yang terakhir penetapan rencana. ${ }^{2}$ Dengan demikian hasil dari penetapart perencanaan sarana prasarana di sekolah dapat diketahui sarana dan prasarana apa saja yang dibutuhkan. ${ }^{2}$

Selain itu dalam perencanaan sarana prasarana terdapat tiga jenis perencanaan sarana prasarana yaitu perencanaan jangka pendek, perencanaan jangka menengah, serta perencanaan jangka panjang. Dalam perencanaan sarana prasarana di MA ini hanya dilakukan satu tahun sekali atau di awal tahun ajaran baru. Sehingga perencanaan dalam jangka pendek saja yang dilakukan dalam perencanaan sarana prasarana karena perencanaan hanya dilakukan setiap satu tahun sekali. Hal ini belum sesuai dengan yang dikemukakan oleh Direktorat Tenaga Kependidikan bahwa perencanaan sarana prasarana terdapat perencanaan jangka pendek, menengah, dan jangka panjang. ${ }^{2}$

Dengan demikian, dalam perencanaan sarana prasarana harus direncanakan dengan sebaik-baiknya agar tujuan dari kegiatan

2 Ikhfan Haris, Manajemen Fasilitas Pembelajarân (Gorontalo: Universitas Negeri Gorontalo Press, n.d.), 30.

2 Barnawi and Arifin, Manajemen Sarana E Prašarana Sekolah, 48.

2 Direktorat Tenaga Kependidikan, "Pengeloláan Sarana Dan Prasarana Sekolah," Kementerian Pendidikan Dan Kebudayaan, n.d. 
manajemen sarana prasarana dapat tercapai secara maksimal serta dapat mewujudkan visi, misi, tujan, dan program madrasah dan tujuan pendidikan secara umum.

\section{Pengadaan Sarana Prasarana di Madrasah Aliyah Swasta}

Pengadaan sarana dan prasana adalah kegiatan penyediaan semua jenis sarana dan prasarana sesuai dengan kebutuhan dalam rangka mencapai tujuan yang telah ditetapkan sebelumnya dengan cara membeli, sumbangan, hibah, dan lain-lain. ${ }^{2}$ Pengadaan sarana dan prasarana merupakan berbagai kegiatan pengadaan alat dan barang berdasarkan rencana yang telah disusun dan ditetapkan. Pengadaan sarana dan prasarana dapat dilakukan dengan membuat sendiri, menyewa, meminjam dan membeli. Pada umumnya, pengadaan sarana prasarana dilakukan dengan cara membeli karena relatif lebih mudah dan dapat dilaksanakan oleh organisasi pengadaan sarana prasarana ini dengan menempuh cara tender. ${ }^{2}$ Adapun tujuan pengadaan yaitu untuk memenuhi kebutuhan sesuai dengan perkembangan dan keperluan dalam mennggantikan barang yang rusak, hilang, dihapuskan, atau sebab lain yang dapat dipertanggung jawabkan sehingga memerlukan pergantian, dan untuk menjaga tingkat persediaan sarana prasarana setiap tahun dan anggaran mendatang. ${ }^{2}$

Proses pengadaan sarana prasarana di MA ini melalui beberapa cara yang dilakukan, meliputi: (1) pembelian dilakukan untuk barang-barang yang tidak membutuhkan dana terlalu besar seperti tempat sampah dan alat kebersihan; (2) penerimaan hibah atau bantuan yang berasal dari pemerintah seperti buku kurikulum kemudian komputer; (3) penyewaan seperti panggung yang digunakan ketika ada acara atau event penting; (4) pinjaman seperti

2 Dermawan, Manajemen Fasilitas Pendidikan. ${ }^{7}$

2 Donni Juni and Agus Garnida, Manajemen Perkantoran (Bandung: Alfabeta, 2013), 14.

2 Prastyawan, "Manajemen Sarana Dan Pråsarana Pendidikan," AlHikmah: Jurnal Studi Keislaman 6, no. 1 (n.d.).

248 Vol. 1 No. 1, November 2019 
kursi plastik apabila terdapat kekurangan jumlah kursi ketika diadakan rapat dengan wali murid; dan (5) perbaikan/rekondisi barang-barang elektronik dan fisik yang sekiranya masih bisa di servis atau diperbaiki seperti kursi, komputer, sound system, dan lain-lain. Hal telah sesuai dengan yang dikemukakan oleh Nurabadi bahwa cara pengadaan sarana prasarana meliputi pembelian, pembuatan sendiri, penerimaan hibah atau bantuan, penyewaan, pinjaman, pendaurulangan, penarikan, dan perbaikan atau rekondisi. $^{3}$

Pengadaan sarana prasarana di MA ini dilaksanakan ketika sarana prasarana tersebut dibutuhkan, sehingga untuk waktu pelaksanaannya dapat dikatakan kondisional melalui beberapa langkah-langkah pengadaan. Langkah pertama yaitu menentukan skala prioritas pengadaan sesuai dengan kebutuhan. Hal ini dilakukan untuk meminimalisir pengadaan sarana prasarana ganda dan memaksimalkan sarana prasarana yang ada. Langkah kedua yaitu mengusulkan proposal pengadaan kepada pihak yayasan guna mendapatkan sarana prasarana yang ada. Langkah ketiga menentukan siapa dan dimana dilakukan pembelian sarana prasarana agar jelas siapa pelaksana dalam pengadaan tersebut. Dan langkah terakhir dilakukan pembelian sarana prasarana yang sedang dibutuhkan.

Langkah di atas telah sesuai dengan yang dikemukakan dalam Keputusan Presiden Nomor 8o Tahun 2003 tentang Pedoman Pelaksanaan Pengadaan Barang/Jasa Pemerintah yang telah disempurnakan dengan Peraturan Menteri Pendidikan dan Kebudayaan Nomor 24 Tahun 2007 tentang Standar Sarana Dan Prasarana Untuk Sekolah Dasar/Madrasah Ibtidaiyah (SD/MI), Sekolah Menengah Pertama/Madrasah Tsanawiyah (SMP/MTS), dan Sekolah Menengah Atas/Madrasah Aliyah (SMA/MA) sebagaimana yang dikutip oleh Direktorat Tenaga Kependidikan yaitu menganalisis kebutuhan dan fungsi sarana dan prasarana,

3 Ahmad Nurabadi, Manajemen Sarana Dan Prasarana Pendidikan (Malang: Universitas Negeri Malang, n.d.). 
mengklasifikasikan sarana dan prasarana yang dibutuhkan, membuat proposal pengadaan sarana dan prasarana yang ditujuakan kepada pemerintah bagi sekolah negeri dan pihak yayasan bagi sekolah swasta. Kemudian apaila disetujui maka akan ditinjau dan dinilai kelayakannya untuk mendapat persetujuan dari pihak yang dituju. Setelah dikunjungi dan disetujui maka sarana dan prasarana akan dikirim ke sekolah yang mengajukan permohonan pengadaan sarana dan prasarana tersebut. ${ }^{3}$

Pada pengadaan sarana prasarana terdapat jenis-jenis pengadaannya. Sama halnya pengadaan yang dilakukan di MA ini. Jenis pengadaan yang dilakukan yaitu pengadaan buku, pengadaan alat, bangunan, dan tanah. Hal ini telah sesuai dengan yang disampaikan oleh Nurabadi bahwa jenis pengadaan sarana prasarana pendidikan meliputi buku, alat, bangunan, dan tanah. ${ }^{3}$ Dalam proses pengadaan juga perlu memperhatikan faktor utility yaitu kegunaannya di sekolah dan standar kualitasnya. ${ }^{3}$ Dalam pengadaan ini harus dilakukan sesuai dengan rencana yang telah disusun sebelumnya dengan memperhatikan skala prioritas yang dibutuhkan oleh sekolah dalam menunjang keberhasilan pelaksanaan proses pembelajaran. ${ }^{3}$

Dengan demikian adanya pengadaan bertujuan untuk menunjang proses pendidikan agar berjalan efektif dan efesien sesuai dengan tujuan yang diinginkan. Pengadaan perlengkapan biasanya dilakukan untuk memenuhi kebutuhan sesuai dengan perkembangan pendidikan.

\section{Pemeliharaan Sarana Prasarana di Madrasah Aliyah Swasta}

Pemeliharaan adalah kegiatan merawat, memelihara dan menyimpan barang-barang sesuai bentuk bentuk jenis barangnya

3 Kependidikan, Manajemen Sarana Prasarand Pendidikan Persekolahan Berbasis Sekolah.

3 Nurabadi, Manajemen Sarana Dan Prasarana²Pendidikan.

3 Haris, Manajemen Fasilitas Pembelajaran. 3

3 Juni and Garnida, Manajemen Perkantoran. ${ }^{4}$ 
sehingga barang tersebut awet dan tahan lama. Pihak yang terlibat dalam pemeliharan barang adalah semua warga sekolah yang terlibat dalam pemanfaatan barang tersebut. Pemeliharaan sarana dan prasana di sekolah untuk mengkondisikan sarana dan prasana tersebut senantiasa siap pakai dan tidak mengalami masalah ketika sedang digunakan. ${ }^{3}$ Ada dua jenis pemeliharan sarana dan prasarana di sekolah, yakni pemeliharaan sehari-hari dan pemeliharaan secara berkala. $^{3}$

Pemeliharaan sarana prasarana di MA ini dilaksanakan melalui beberapa langkah atau tahapan. Langkah pertama adalah pembentukan tim khusus kebersihan sarana prasarana sebagai garda depan dalam membersihkan sarana prasarana yang ada secara rutinan. Langkah kedua adalah membuat list daftar sarana prasarana dan prosedur pemeliharaannya, setelah tim khusus kebersihan telah dibentuk maka diperlukan list dan prosedur pemeliharaan sarana prasarana mana saja yang harus dipantau secara rutin dan secara berkala. Langkah ketiga adalah menentukan jadwal pemeliharaan secara terus menerus dan secara berkala agar jelas pelaksanaan pemeliharaan sarana prasarana yang ada. Langkah terakhir adalah pelaksanaan pemeliharaan.

Kegiatan pemeliharaan di MA ini telah sesuai dengan yang dikemukakan oleh Ananda dan Banurea bahwa tahapan pemeliharaan meliputi membentuk tim pelaksana pemeliharaan preventif di sekolah. Kemudian membuat daftar sarana dan prasarana termasuk seluruh pemeliharaan yang ada di sekolah. Selanjutnya menyiapkan jadwal tahunan kegiatan perawatan untuk setiap perawatan dan fasilitas sekolah. Kemudian menyiapkan lembar evaluasi untuk menilai hasil kerja perawatan pada masingmasing bagian di sekolah. Dan yang terakhir memberi penghargaan bagi mereka yang berhasil meningkatkan kinerja peralatan sekolah

3 Muhammad Kristiawan, Dian Safitri, and Rena Lestari, Manajemen Pendidikan (Sleman: Deepublish, n.d.).

3 Ananda and Banurea, "Manajemen Sarana Dán Prasarana Pendidikan," 50. 
dalam rangka meningkatkan kesadaran dalam merawat sarana dan prasarana di sekolah. ${ }^{3}$

Dengan demikian pengadaan sarana prasarana harus benarbenar dilakukan untuk mengoptimalkan usia pakai peralatan agar lebih lama serta menjamin kesiapan operasional untuk mendukung kelancaran pembelajaran. Adanya pemeliharaan yang baik dapat mencegah terjadinya kerusakan sarana prasarana akan menjadi lebih terkontrol. Selain itu sarana prasarana yang terpelihara dengan baik akan mendukung proses pembelajaran dengan baik pula. ${ }^{3}$

\section{Pengawasan Sarana Prasarana di Madrasah Aliyah Swasta}

Pengawasan terhadap sarana dan prasarana pendidikan adalah usaha yang dilakukan dalam pengontrolan terhadap sarana dan prasarana sebagai bagian dari aktivitas menjaga, memelihara, dan memanfaatkan sarana dan prasarana dengan sebaik mungkin demi keberhasilan pembelajaran di sekolah. ${ }^{3}$ Dengan adanya pengawasan, maka dapat menjamin program-program telah berjalan sesuai dengan perencanaan untuk mencapai tujuan. ${ }^{4}$ Setiap program maupun kegiatan selalu terdapat pengawasan di dalamnya, tak terkecuali kegiatan manajemen sarana dan prasarana. Pengawasan sarana dan prasarana dilakukan dalam rangka mengendalikan jalannya manajemen sarana dan prasarana agar sesuai dengan ketentuan yang ada. ${ }^{4}$

Pengawasan sarana prasarana di MA ini dilakukan oleh seluruh lapisan di madrasah, mulai dari kepala madrasah, guru, pegawai tata usaha, petugas khusus kebersihan, siswa, dan wali murid. Dengan melibatkan seluruh lapisan di madrasah dalam

3 Ananda and Banurea, "Manajemen Sarana Dān Prasarana Pendidikan."

3 Sherly et al., Manajemen Pendidikan Tinjauan Teori Dan Praktis (Bandung: Widina, 2020), 115.

3 Ananda and Banurea, "Manajemen Sarana Dån Prasarana Pendidikan."

4 Kependidikan, "Pengelolaan Sarana Dan Prasârana Sekolah."

4 Matin and Nurhattati Fuad, Manajemen ${ }^{1}$ Sarana Dan Prasarana Pendidikan (Konsep Dan Aplikasinya (Jakarta: Kharisma Putra Utama Offset, n.d.).

252 Vol. 1 No. 1, November 2019 
pengawasan diharapkan dapat meng-cover seluruh sarana prasarana di madrasah sehingga kondisi sarana prasarana dapat terjamin kualitasnya. Hal ini telah sesuai dengan yang dikemukakan oleh Ananda dan Banurea bahwa Pengawasan sarana dan prasarana dilakukan bersama antara pendidik dan tenaga kependidikan di sekolah, orang tua/wali murid, komite sekolah, dan stakeholders lainnya. ${ }^{4}$

Dalam pengawasan sarana prasarana di MA ini dilakukan dengan beberapa langkah atau tahapan. Langkah pertama adalah pihak yang terlibat melaporkan hasil pengawasan kepada wakil kepala madrasah bagian sarana prasarana. Langkah kedua adalah pihak madrasah membuat pelaporan hasil pengawasan. Langkah terakhir yaitu pelaporan hasil pengawasan kondisi sarana prasarana dilakukan dalam kurun waktu 6 bulan sekali serta 1 tahun sekali. Pelaporan ini dilakukan oleh MA Muhammadiyah o4 Beton kepada pihak Yayasan. Hal ini telah sesuai dengan yang dikemukakan oleh Ananda dan Banurea bahwa hasil dari pengawasan, sarana dan prasarana harus dilaporkan dalam kurun waktu tertentu (satu semester dan satu tahun). Pelaporan tersebut penting untuk mengetahui secara riil sarana dan prasarana yang ada di sekolah dan keadaannya. ${ }^{4}$

Dengan demikian pengawasan sarana prasarana memiliki peran yang cukup penting dalam manajemen sarana prasarana. Pengawasan sarana dan prasarana dilakukan agar penggunaan dan pemeliharaan dapat berjalan dengan baik dan tidak menganggu proses pembelajaran yang berlangsung sehingga prestasi belajar siswa dapat meningkat.

\section{Simpulan}

Manajemen sarana prasarana pendidikan merupakan suatu proses kegiatan untuk dapat mengola sarana prasarana secara sistematis dan terstruktur dan menciptakan pendidikan yang

\footnotetext{
4 Ananda and Banurea, "Manajemen Sarana Dån Prasarana Pendidikan."

4 Ananda and Banurea.
} 
bermutu dan berkualitas. Oleh karena itu, diperlukan manajemen sarana prasarana pendidikan yang baik dan tepat melalui proses perencanaan, pengadaan, pemeliharaan dan pengawasan. Implementasi manajemen sarana prasarana pendidikan di MA swasta dilakukan melalui pertama, perencanaan dilakukan setiap sebelum awal tahun pembelajaran, terdiri dari kegiatan penyusunan daftar kebutuhan, estimasi biaya, menetapkan skala prioritas dan menetapkan rencana pengadaan. Kedua, pengadaan melalui pembelian, penerimaan hibah, penyewaan, pinjaman dan rekondisi. Ketiga, pemeliharaan dilakukan dengan cara membentuk tim pemeliharaan, menyusun daftar pemeliharaan, menentukan jadwal pemeliharaan secara rutin dan berkala, dan evaluasi pemeliharaan. Keempat, pengawasan dilakukan melalui waka sarpras melaporkan hasil pengawasan kepada kepala madrasah, penyusunan laporan pengawasan, dan pelaporan kepada pihak yayasan setiap enam bulan sekali dan setahun sekali.

\section{Referensi}

Aedi, Nur. Manajemen Sarana Dan Prasarana. Jakarta: Insan Rabbani, n.d.

Ananda, Rusydi, and Oda Kinanta Banurea. "Manajemen Sarana Dan Prasarana Pendidikan," n.d.

Arikunto, Suharsimi, and Lia Yuliana. Manajemen Pendidikan. Yogyakarta: Aditya Media, 2009.

Barnawi, and Muhammad Arifin. Manajemen Sarana \& Prasarana Sekolah. Yogyakarta: Ar-Ruzz Media, 2017.

Dermawan, Oki. Manajemen Fasilitas Pendidikan. Jakarta: Edu Pustaka, n.d.

Fathurrahman, and Rizky Oktaviani Putri Dewi. "Manajemen Sarana Dan Prasarana Pendidikan Mendukung Proses Belajar Siswa Di SDN Puter 1 Kembangbahu Lamongan.” Reforma: Jurnal 
Pendidikan Dan Pembelajaran 8, no. 1 (n.d.).

Fattah, Nanang. Ekonomi Dan Pembiayaan Pendidikan. Bandung: Rosdakarya, 2012.

Haris, Ikhfan. Manajemen Fasilitas Pembelajaran. Gorontalo: Universitas Negeri Gorontalo Press, n.d.

Huda, Mohammad Nurul. "Optimalisasi Sarana dan Prasarana Dalam Meningkatkan Prestasi Belajar Siswa.” Ta'dibi: Jurnal Manajemen Pendidikan Islam 6, no. 2 (n.d.).

Jambak, Maryam. "Manajemen Sarana dan Prasarana SD Negeri pada Daerah Terpencil (Studi Kasus SDN 280 Aek Manggis Kecamatan Batang Kabupaten Mandiling Natal"," n.d.

Juni, Donni, and Agus Garnida. Manajemen Perkantoran. Bandung: Alfabeta, 2013.

Kependidikan, Direktorat Tenaga. Manajemen Sarana Prasarana Pendidikan Persekolahan Berbasis Sekolah. Departemen Pendidikan Nasional, n.d.

___ . "Pengelolaan Sarana dan Prasarana Sekolah." Kementerian Pendidikan Dan Kebudayaan, n.d.

Kristiawan, Muhammad, Dian Safitri, and Rena Lestari. Manajemen Pendidikan. Sleman: Deepublish, n.d.

Machali, Imam dan Ara Hidayat. "The Handbook of Education Management: Teori dan Praktik," n.d.

Matin, and Nurhattati Fuad. Manajemen Sarana Dan Prasarana Pendidikan (Konsep Dan Aplikasinya. Jakarta: Kharisma Putra Utama Offset, n.d.

Nurabadi, Ahmad. Manajemen Sarana dPrasarana Pendidikan. Malang: Universitas Negeri Malang, n.d.

Prastyawan. "Manajemen Sarana dan Prasarana Pendidikan.” AlHikmah: Jurnal Studi Keislaman 6, no. 1 (n.d.). 
Sherly, Leni Nurmiyanti, Hery YNto, Fifit Frirmadani, Safrul Nuramila, Sonia Nur Rahmi, Suharto Lasmono, et al. Manajemen Pendidikan Tinjauan Teori dan Praktis. Bandung: Widina, 2020.

Sinta, Ike Malaya. "Manajemen Sarana dan Prasarana." Jurnal Islamic: Education Manajemen 4, no. 1 (n.d.).

Soetopo. Administrasi Pendidikan. Malang: IKIP Malang, 1998.

Sonia, Nur Rahmi. Manajemen Pendidikan: Tinjauan, Teori dan Praktis. Bandung: Widina, n.d.

Suryani. "Manajemen Sarana Prasarana dan Prestasi Belajar Peserta Didik.” Al-Idarah: Jurnal Kependidikan Islam 7, no. 2 (n.d.).

Trisnawati, Cut Zahri Harun, and Nasir Usman. "Manajemen Sarana dan Prasarana Pendidikan dalam Meningkatkan Mutu Pembelajaran di SD Negeri Lamteubee Aceh Besar." Jurnal Magister Administrasi Pendidikan 7, no. 1 (n.d.).

Yamin, Muhammad, Tobari, and Missriani. "Manajemen Sarana dan Prasarana dalam Meningkatkan Hasil Belajar Siswa di SD IT Kautsar Ilmi Tanjung Raja." Jurnal Intelektualita: Keislaman, Sosial, dan Sains 9, no. 1 (n.d.).

Yudhi, Alex Aldha. "Pengembangan Mutu Pendidikan Ditinjau dari Segi Sarana dan Prasarana (Sarana Dan Prasarana PPLP)." Cerdas Syifa 1, no. 1 (2012): 1-9. 